\title{
Completion sequence and cloning of the infectious cDNA of a chb isolate of cucumber green mottle mosaic virus
}

\author{
M. ZHONG ${ }^{1 \Phi}, \mathrm{X} . \mathrm{ZHAO}^{1 \Phi}$, Y. $\mathrm{LIU}^{2}, \mathrm{Y} . \mathrm{WANG}^{1 *}, \mathrm{~K} . \mathrm{CAO}^{1}$ \\ ${ }^{1}$ College of Plant Protection, Agricultural University of Hebei, No. 2596, South Lucky Street, Baoding 071001, P. R. China; ${ }^{2}$ Institute of \\ Plant Protection, Chinese Academy of Agricultural Sciences, No. 2, West Yuan Ming Yuan Road, Beijing 100193, P. R. China
}

\begin{abstract}
Summary. - Cucumber green mottle mosaic virus (CGMMV) is an important and widespread seed-borne virus that infects Cucurbitaceous plants. It is a member of the genus Tobamovirus in the family Virgaviridae with a monopartite (+) ssRNA genome. Here we report the complete genome sequence, construction and testing of the infectious clones of a chb isolate of CGMMV. Full-length CGMMV cDNA was cloned into the vector pUC19. The linearized vector containing full-length cDNA was used as template for in vitro transcription, and the synthesized capped transcript was highly infectious in Chenopodium amaranticolor and cucumber (Cucumis sativus). Inoculated plants showed symptoms typical of CGMMV infection. The infectivity was confirmed by mechanical transmission to new plants, RT-PCR and western blot. Progeny virus derived from infectious transcripts had the same biological and biochemical properties as wild-type virus. To our knowledge, this is the first detailed report of a biologically active transcript from CGMMV.
\end{abstract}

Keywords: cucumber green mottle mosaic virus; Tobamovirus; cucumber; infectious clone

\section{Introduction}

Cucumber green mottle mosaic virus (CGMMV) is an emerging disease pathogen in watermelons in China. In 2005, a disease outbreak occurred in watermelon fields in Liaoning province which was confirmed to be caused by CGMMV (Chen et al., 2006). CGMMV is a seed-borne virus that infects Cucurbitaceous plants and causes severe mosaic symptoms, discoloration and deformation (Celix et al., 1996; Ali et al., 2004). CGMMV remains a serious threat to cucurbit plant production, because seed-borne viruses act as initial inoculum in their hosts. CGMMV infected seeds can cause significant loss of yield (Francki et al., 1986; Kim

*Corresponding author. E-mail: wyn3215347@163.com; phone: +86-312-7528157. ${ }^{\varphi}$ These authors contributed equally to this work.

Abbreviations: CGMMV = cucumber green mottle mosaic virus; KGMMV = Kyuri green mottle mosaic virus; ZGMMV = zucchini green mottle mosaic virus and Lee, 2000). In December 2006, the Chinese Ministry of Agriculture imposed a quarantine measure to restrict movement of watermelon seeds and seedlings to China (Chen and Li, 2007). In 2009, we reported the distribution pattern of CGMMV in China during 2007 to 2008. The virus has spread in five provinces of China, including Liaoning, Hebei, Guangdong, Hubei and Shandong (Liu et al., 2009). The complete genome sequence of the isolates from Liaoning and Shandong has been obtained, but to our knowledge, the genome information of the other isolates has not been described.

CGMMV belongs to the genus Tobamovirus, which consists of a positive-sense single-stranded RNA encoding at least four proteins. The 5'-proximal ORFs encode the short and the long viral replicase, the third ORF encodes the movement protein (MP). The 3'-proximal ORF encodes the coat protein (CP). CGMMV was first isolated in the United Kingdom in 1935 (Ainsworth, 1935). It has been reported in Europe, Israel, Saudi Arabia, India, Pakistan, Korea, Japan and China (Komuro et al., 1968; Antignus et 
al., 1990; Lee et al., 1990; Celix et al., 1996; Lee, 1996; Ali et al., 2004; Chen and Li, 2007). To date, several isolates of CGMMV have been described and they are closely related to CV3 and CV4 isolates from the U.K (Ainsworth, 1935, Francki et al., 1986), including CGMMV-W (watermelon) and the highly similar CGMMV-SH from Japan (Ugaki et al., 1991); CGMMV-Sp from Spain (Celix et al., 1996); an Indian isolate C (Vani and Varma, 1993) and CGMMV-Is from Israel (Antignus et al., 1990). Two other viruses that were initially determined as the cucumber (CGMMV-C) and the Yodo (CGMMV-Yodo) isolates of CGMMV were subsequently considered to be isolates of a distinct virus, named Kyuri green mottle mosaic virus (KGMMV) and the Yodo isolate of KGMMV (KGMMV-Y), respectively, based on serological and sequencing studies (Tan et al., 2000). CGMMV-KOM, CGMMV-KW and CGMMV watermelon strains were reported in Korea (Kim et al., 2003). Three Chinese isolates, CGMMV-LN and CGMMV-Liaoning from Liaoning province, CGMMV-TANG from Shandong province, had been reported (Chen et al., 2006; Liu et al., 2009). Here we report the genome of CGMMV-chb isolate, which was isolated from Hebei province of China.

To date, 10 infectious cDNA clones for Tobamovirus have been obtained: tobacco mosaic virus (TMV) (Meshi et al., 1986), tomato mosaic virus (ToMV) (Weber et al., 1992), odontoglossum ringspot virus (ORSV) (Yu and Wong, 1998), Kyuri green mottle mosaic virus (KGMMV) (Yoon et al., 2001), zucchini green mottle mosaic virus (ZGMMV) (Yoon et al., 2002), obuda pepper virus (ObPV) (Junqueira et al., 2014 ), turnip vein-clearing virus (TVCV) (Zhang et al., 1999), pepper mild mottle virus (PMMoV) (Ichiki et al., 2009), ribgrass mosaic virus (RMV) (Ryu et al., 2012), maracuja mosaic virus (MarMV) (Song et al., 2006), and Chinese rape mosaic virus (CRMV) (Aguilar et al., 1996).
However, little information has been reported for CGMMV so far.

In this study, we determined the complete nucleotide sequence and analyzed the genome organization for the chb isolate of CGMMV (KJ658958). We studied the relationship of chb isolate to other isolates submitted in GenBank. We also described the construction of a full-length cDNA clone of CGMMV-chb, from which highly infectious transcripts could be synthesized. The biological activity of the in vitro transcripts of CGMMV-chb in local lesions of the host and systemic host plants were described. Such an in vitro transcription system could be very useful for manipulating the viral RNA to study genome functions or plant-virus interaction mechanism.

\section{Materials and Methods}

Virus and plant sources and viral RNA extraction. The isolate chb of CGMMV (CGMMV-chb) used in this study was originally isolated from diseased watermelon plants in Hebei province of China, which was isolated and purified from the local lesion of the host Chenopodium amaranticolor and then propagated on systemic host cucumber (Cucumis sativus) cv. Jin You No.1. Cucumber cv. Jin You No.1 and Ch. amaranticolor were grown for CGMMV in vitro transcripts infectivity test. Total RNA was extracted from sample tissues using Trizol Reagent as previously described by Liu et al. (2009). The total RNA was kept at $-80^{\circ} \mathrm{C}$ and used as template for cDNA synthesis and as a positive control of transcript bioassay experiments.

Primer design, cDNA synthesis, molecular cloning and sequencing for the genome of CGMMV-chb. The nucleotide sequences of CGMMV-chb were obtained using a series of primers (Table 1), which were based on the conserved sequences of published genomes

Table 1. List of primers designed for determination of CGMMV-chb genome, construction of infectious cDNA clone and identification of CGMMV

\begin{tabular}{|c|c|c|c|c|}
\hline Primer & Primer sequence in $5^{\prime}-3^{\prime}$ orientation & Position $^{\mathrm{a}}$ & Product size & Purpose \\
\hline pr5RACE1-R & CTCCATATCTTCAGTTACATCCA & 1922-1944 & 1944 bp & 5'-RACE \\
\hline pr5RACE2-R & CATGTGTGTGTCTGCTCTGACCA & 992-1014 & 1014 bp & 5'-RACE \\
\hline prCGchb2-F & CATGTGAAGATATGGATGTAACTGAAG & 1910-1936 & \multirow{2}{*}{$1563 \mathrm{bp}$} & \multirow{2}{*}{ Determination of genome } \\
\hline prCGchb2-R & GCAAACATGGTCAAGATCGACTG & $3451-3473$ & & \\
\hline prCGchb3-F & GATGCAGTTACAAGTATAATAGCGGATG & 3409-3436 & \multirow{2}{*}{$1617 \mathrm{bp}$} & \multirow{2}{*}{ Determination of genome } \\
\hline prCGchb3-R & CGAGTTCTCGACTGACACCTTAC & 5004-5026 & & \\
\hline pr3RACE1-F & GAGTGATAAGCGCCTTTTCCGTAG & $4959-4982$ & 1465 & 3'-RACE \\
\hline pr3RACE2-F & GTCTGTCGTCTCTTCCGATCAG & $5542-5563$ & $882 \mathrm{bp}$ & 3'-RACE \\
\hline prCGQC-F & $\begin{array}{l}\text { ATGGATCCTAATACGACTCACTATAGGGTTTTAATTTT } \\
\text { TATAATTAAAC }\end{array}$ & $1-22$ & \multirow[t]{2}{*}{$6424 \mathrm{bp}$} & \multirow[t]{2}{*}{$\begin{array}{l}\text { Construction of } \\
\text { infectious clone }\end{array}$} \\
\hline prCGQC-R & CAGAGCTCTACGTATGGGCCCCTACCCGGGG & 6408-6424 & & \\
\hline prCGCP-F & CTTTGACAAAGTTCCTATTTCAGCG & 5605-5629 & \multirow{2}{*}{$721 \mathrm{bp}$} & \multirow{2}{*}{ Identification of CGMMV } \\
\hline prCGCP-R & TGAGCAAACCGTTCGATTTA & $6307-6326$ & & \\
\hline
\end{tabular}

aThe reference accession number (National Center for Biotechnology Information) for the determination of the primer positions is CGMMV-KW (AF417242). prCGQC-F: BamHI is indicated by shading. T7 promoter is shown in italics. prCGQC-R: SacI and SnaBI is indicated by shading. 
of CGMMV. The amplification of the 5' part and 3' part of the genome was carried out using 5 '-full RACE kit with TAP (tobacco acid pyrophosphatase) and 3'-full RACE core set with PrimeScriptTM RTase (TaKaRa, China) according to the manufacture's instructions. Two antisense-oligonucleotides were synthesized for rapid amplification of cDNA 5'-ends (5'-RACE) (pr5RACE1-R and pr5RACE2-R). Two sense oligonucleotides were also synthesized for 3'-RACE (pr3RACE1-F and pr3RACE2-F). Successful amplification of nucleotide segments of the expected size was confirmed by electrophoresis in $1 \%(\mathrm{w} / \mathrm{v})$ agarose gel. The PCR products were then purified by the DNA gel extraction kit (TaKaRa, China) and cloned into the pMD18-T vector (TaKaRa) according to the manufacture's instructions. The recombinant vectors were transformed into $E$. coli strain JM109. For each segment at least three independently isolated clones were sequenced (Shanghai Sangon Biotech Company, China). The sequences were compared with the corresponding virus sequence retrieved from the GenBank database.

Sequence and phylogenetic analysis. Sequence segments were assembled by VECTOR NTI, version 10.0 software (Informax, USA). Other twelve CGMMV genome sequences were obtained from NCBI, including CGMMV_TANG (HM008919), CGMMV-LN (EU352259), CGMMV-KOM (AF417243), CGMMV-KW (AF417242), CGMMVSH (D12505), CGMMV-W (AB015146), Liaoning isolate of CGMMV (EF611826), CGMMV strain Watermelon (AB369274), CGMMV isolate Ah (KF155232), CGMMV isolate Ec (KF155231), CGMMV isolate Rd (KF155230), CGMMV isolate TY (KF155229), KGMMV (NC_003610) and ZGMMV (NC_003878) were used as outgroup control. The multiple alignments were made using the Align in VECTOR NTI, version 10.0 software. Sequence comparison or phylogenetic tree construction was made using a neighborjoining of Bootstrap test in MEGA5.0 (version 5.0, Japan).

Construction of a full-length cDNA clone of CGMMV-chb. Fulllength genome of CGMMV-chb was amplified with prCGQC-F and prCGQC-R by RT-PCR (Table 1 and Fig. 1). The prCGQC-F, contains $\mathrm{Bam} \mathrm{HI}$ recognition site and T7 RNA promoter sequences and two additional $G$, which can improve the efficiency of transcription. The prCGQC-R contains SnabI and SacI site for cloning and in vitro transcription as shown in Fig. 1. PCR was performed with first-strand cDNA from viral RNAs and LA Taq ${ }^{\text {mi }}$ (Takara) to amplify long template DNA. The PCR program was performed in a standard thermocycler (Bioer, China), with the following conditions: denaturation at $94^{\circ} \mathrm{C}$ for $2 \mathrm{~min}$, followed by 30 cycles of denaturation at $98^{\circ} \mathrm{C}$ for $10 \mathrm{sec}$, annealing at $55^{\circ} \mathrm{C}$ for $30 \mathrm{sec}$, and extension at $72^{\circ} \mathrm{C}$ for $7 \mathrm{~min}$. The PCR products $(5 \mu \mathrm{l})$ were analyzed by electrophoresis in $1.0 \%$ agarose gel containing $0.5 \mu \mathrm{g} / \mathrm{ml}$ ethidium bromide in $1 \times \mathrm{TAE}$ buffer $(40 \mathrm{mmol} / \mathrm{l}$ tris-acetate, $1 \mathrm{mmol} / \mathrm{l}$ EDTA) for $30 \mathrm{~min}$ at $120 \mathrm{~V}$. Amplified products were digested with $\mathrm{BamHI}$ and SacI restriction endonucleases and cloned into pUC19 plasmid. The full-length cDNA clone was used as template DNA for in vitro transcription reaction.

In vitro transcription and infectivity assay. Full-length cDNA clone of the CGMMV-chb in pT7CGBS was linearized by SnaBI and used as template for in vitro transcription. The reaction was performed with T7 RNA polymerase in the presence of Ribo m7G cap analog (Takara) according to manufacture's instructions. Quantity and quality of RNA transcripts were assayed in $1.0 \%$ agarose gel. Carborundum-dusted cotyledons of cucumber and Ch. amaranticolor plants were inoculated by $2.0 \mu \mathrm{g}$ to $3.0 \mu \mathrm{g}$ of the transcripts. Appearance and development of virus symptoms on inoculated plants were observed and compared to those of wild virus RNA. RT-PCR and western blot analyses were performed to verify the infectivity.

Western blot analyses. Western blot was performed using commercial antibody against CGMMV (Agdia Inc., USA) according to the manufacture's instructions. Crude extracts of the inoculated and healthy tissues were separated by $15 \%$ SDS-PAGE and transferred onto a nitrocellulose (NC) membrane using electrotransfer. Hybridization was carried out in a hybridization incubator with homologous antibody for western blot analysis (Ryu et al., 2012).

\section{Results}

\section{Molecular characterization of CGMMV-chb}

The complete genome of CGMMV-chb (GenBank Acc. No. KJ658958) is $6424 \mathrm{nt}$ in length. Nucleotide sequence analysis of CGMMV-chb indicated the presence of four ORFs and two UTRs organized similarly to that of other CGMMV isolates. The first two ORFs encode the $128.7 \mathrm{kDa}$

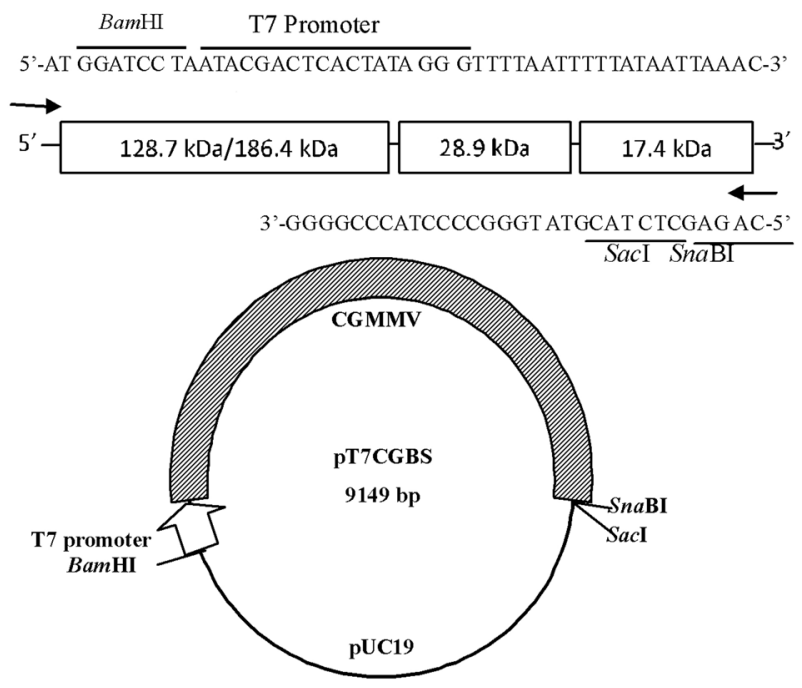

Fig. 1

Construction of a full-length cDNA clone (pT7CGBS) of cucumber green mottle mosaic virus (CGMMV)

The 5 -end and $3^{\prime}$-end primer sequences are shown in detail on the corresponding region. The sites of T7 RNA promoter and restriction endonuclease are marked in the map of the cDNA clone. 
(nt 61-3492) pre-read through and $186.4 \mathrm{kDa}$ read through (nt 61-5004) proteins. ORF 3 encodes the $28.9 \mathrm{kDa}$ protein involved in cell to cell movement (MP, nt 4994-5785) and ORF 4 encodes the $17.4 \mathrm{kDa} \mathrm{CP}$ (nt 5763-6245). It also has approximately 60 nucleotides of 5'UTRs and 179 nucleotides of uncompleted 3'UTRs.

\section{Phylogenetic analysis}

A sequence comparison was made between CGMMV-chb and all other isolates of CGMMV as well as KGMMV and ZGMMV as outgroup from GenBank. The results showed

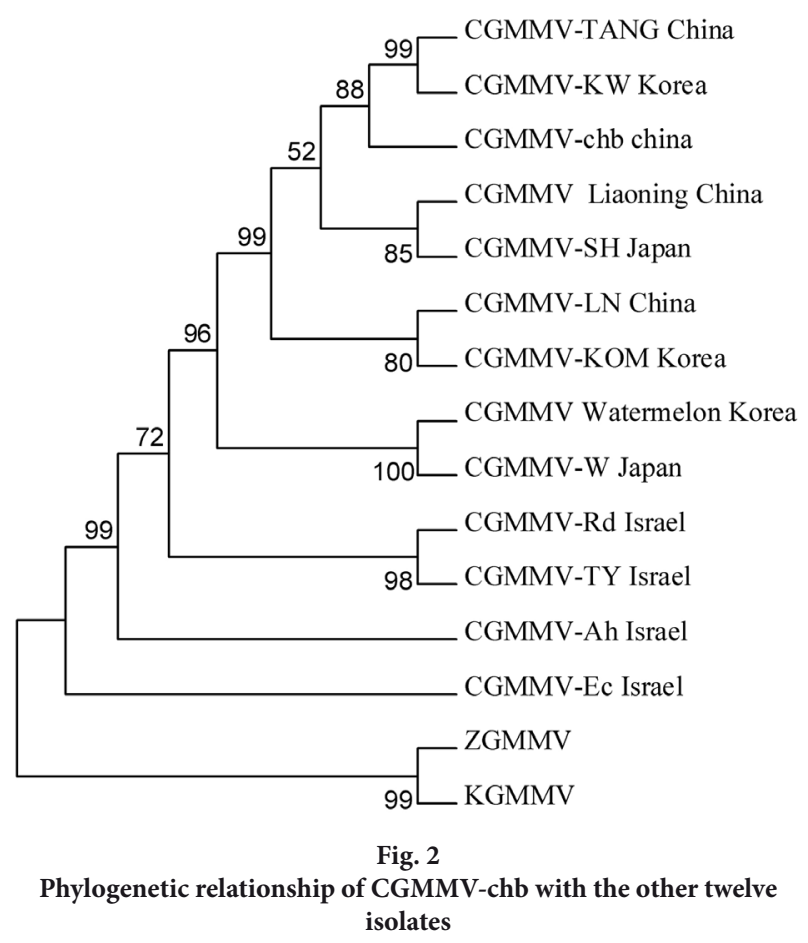

that the full genome sequence of CGMMV-chb shared 94\% 100\% sequence identity with the other twelve isolates and the highest sequence identity (100\%) with CGMMVKW, and a relatively low sequence identity (94\%) with CGMMV isolate Ec (Table 2). The sequence of each ORF, 3'UTRs, 5'UTRs was also compared between CGMMV-chb and other CGMMV isolates. The result showed that CGMMV-chb shared 94\% 100\% sequence identity with other isolates for $129 \mathrm{kDa}$ and $186 \mathrm{kDa}$ protein, $96 \% \sim 100 \%$ for MP, 92\% 100\% for CP, $95 \% \sim 100 \%$ for 5'UTR and 98\% 100\% for 3'UTR. 3'UTR is the most conserved part in the genome (Table 2). The sequence of four ORFs between CGMMVchb and other isolates was also compared at the amino acid level, which showed that CGMMV-chb shared 100\% identity with CGMMV-KOM, CGMMV-KW, CGMMV-LN (EU352259), CGMMV-SH (D12505) and CGMMV-TANG (Table 2), indicating that the six isolates may be the closest among all CGMMV isolates. Phylogenetic trees based on genome sequence alignments indicated that all the CGMMV isolates are closely related, and formed a distinctive cluster. However CGMMV-chb was closer to CGMMV-KW and Liaoning isolate of CGMMV than other isolates. KGMMV belongs to a separate clade and is in the same sub-cluster with ZGMMV (Fig. 2).

\section{Infectivity of in vitro transcript of CGMMV-chb from cloned cDNA}

The full-length cDNA of CGMMV-chb was amplified by RT-PCR with 5 '-end upstream (prCGQC-F) and 3'-end downstream primers (prCGQC-R) (Table 1 and Fig. 1). High quality full-length cDNA product was obtained by RT-PCR, then digested and cloned to plasmid pUC19. The recombinant vector pT7CGBS was analyzed by single digestion (SnaBI, SacI, EcoRI, BamHI) and double digestion (BamHI and SacI). The result showed the construction of pT7CGBS

Table 2. Nucleotide and amino acid sequence identities (\%) comparison between CGMMV-chb and other isolates

\begin{tabular}{|c|c|c|c|c|c|c|c|c|c|c|c|}
\hline \multirow{2}{*}{ Source of virus } & \multirow{2}{*}{$\begin{array}{c}\text { Genome (\%) } \\
\text { nt }\end{array}$} & \multicolumn{2}{|c|}{$129 \mathrm{~K}(\%)$} & \multicolumn{2}{|c|}{$186 \mathrm{~K}(\%)$} & \multicolumn{2}{|c|}{ MP (\%) } & \multicolumn{2}{|c|}{$\mathrm{CP}(\%)$} & \multirow{2}{*}{$\begin{array}{c}\text { 5'UTR (\%) } \\
\text { nt }\end{array}$} & \multirow{2}{*}{$\begin{array}{c}\text { 3'UTR (\%) } \\
\text { nt }\end{array}$} \\
\hline & & nt & aa & nt & aa & nt & aa & nt & aa & & \\
\hline CGMMV-Ah & 98 & 97 & 99 & 97 & 99 & 99 & 100 & 97 & 99 & 98 & 98 \\
\hline CGMMV-Ec & 94 & 94 & 99 & 94 & 99 & 96 & 98 & 92 & 98 & 98 & 98 \\
\hline CGMMV-Rd & 98 & 98 & 99 & 98 & 99 & 99 & 99 & 97 & 99 & 95 & 98 \\
\hline CGMMV-TY & 98 & 98 & 99 & 98 & 99 & 99 & 100 & 98 & 99 & 97 & 99 \\
\hline CGMMV-KOM & 99 & 99 & 100 & 99 & 100 & 98 & 100 & 100 & 100 & 100 & 98 \\
\hline CGMMV-W & 98 & 97 & 99 & 97 & 99 & 100 & 99 & 99 & 100 & 100 & 100 \\
\hline CGMMV-KW & 100 & 99 & 100 & 99 & 100 & 100 & 100 & 100 & 100 & 98 & 100 \\
\hline CGMMV Liaoning & 99 & 99 & 99 & 99 & 99 & 100 & 99 & 100 & 100 & 100 & 100 \\
\hline CGMMV Watermelon & 99 & 99 & 99 & 99 & 99 & 100 & 99 & 100 & 100 & 100 & 100 \\
\hline CGMMV-LN & 99 & 99 & 100 & 99 & 100 & 100 & 100 & 100 & 100 & 100 & 100 \\
\hline CGMMV-SH & 99 & 99 & 100 & 99 & 100 & 100 & 100 & 100 & 100 & 100 & 100 \\
\hline CGMMV-TANG & 99 & 99 & 100 & 99 & 100 & 100 & 100 & 99 & 100 & 98 & 99 \\
\hline
\end{tabular}


Table 3. Assay of infectivity of in vitro transcript RNAs product of CGMMV-chb transcribed from cloned cDNA on two host plants ${ }^{\mathrm{a}}$

\begin{tabular}{lcc}
\hline & Cucumber & Ch. amaranticolor \\
\hline Inoculated plant & 9 & 10 \\
Infected plant & 5 & 10 \\
Incident rate (\%) & 56 & 100 \\
\hline
\end{tabular}

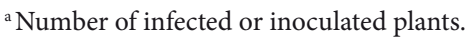

is correct (Fig. 3 Lane 1-6). The full-length cDNA clone pT7CGBS was linearized with SnaBI and transcribed with T7 RNA polymerase. A 6424 bp long RNA transcript was produced (Fig. 3 Lane 7 ) and mechanically inoculated in to two plant species. The pT7CGBS transcripts were infectious in 5 of $9(56 \%)$ cucumber plants and 10 of 10 (100\%) Ch. amaranticolor plants, respectively (Table 3 ). The symptoms and the timing of appearance of the pT7CGBS transcripts were identical to those induced by the wild CGMMV RNA on cucumber (Fig. 4c) and Ch. amaranticolor (Fig. 4d). The presence of CGMMV in inoculated plants was determined by RT-PCR with CGMMV specific primers (prCGCP-F and prCGCP-R) or by western blot analyses. The results for cucumber are shown in Fig, $4 \mathrm{a}$ and Fig. $4 \mathrm{~b}$. The amounts of viral CP detected were at a similar level in plants inoculated with in vitro transcripts (Fig. $4 \mathrm{~b}$ lane 2 and lane 3 ) and control plants inoculated with wild-type CGMMV RNA (Fig. 4b, lane 1). The pT7CGBS is the first CGMMV cDNA clone from which highly infectious transcript can be produced.

Virus from plants infected by in vitro transcript was inoculated to healthy plants, producing the same symptoms (data not shown). Progeny virus derived from infectious in vitro

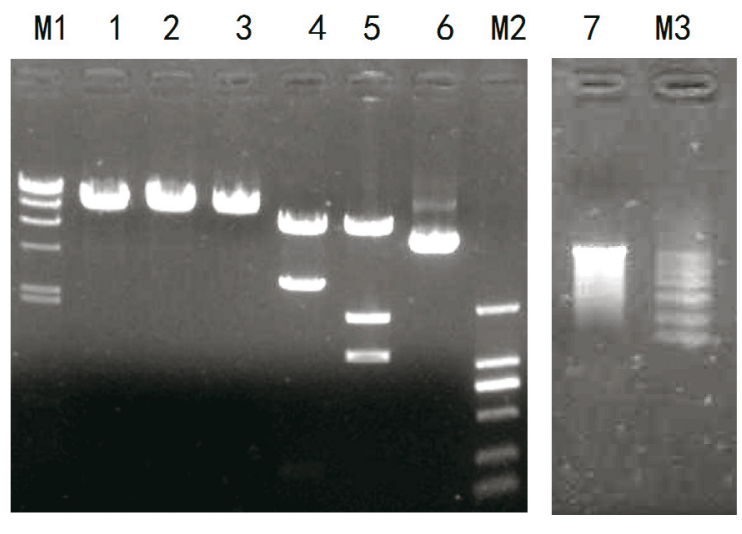

Fig. 3

The verification of pT7CGBS by restriction endonuclease digestion and in vitro transcription using linearized pT7CGBS as template $\lambda$-HindIII digest DNA marker (M1); DL2,000 DNA Marker(M2); pT7CGBS digested by SnaBI (1); pT7CGBS digested by BamHI (2); p T7CGBS digested by SacI (3); pT7CGBS digested by BamHI and SacI (4); pT7CGBS digested by EcoRI (5); pT7CGBS plasmid control (6); in vitro transcripts using linearized pT7CGBS as template (7); RL6000 RNA Marker (M3) transcripts was efficiently transmitted by sap inoculation to its host plants (data not shown), showing the sTable replication competency of the virus derived from the clone. These results indicate that we have obtained a full-length infectious clone of a CGMMV-chb with high biological activity yielding the in vitro transcript which can yield symptoms indistinguishable from those of the native virus.

\section{Discussion}

Cucurbitaceous plants, such as cucumber, melon, watermelon, zucchini squash, cantaloupe and other, are economically important vegetable crops in China. CGMMV

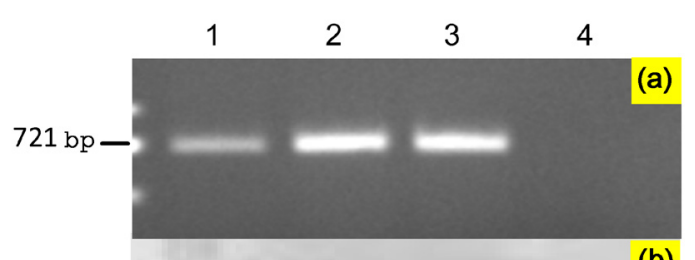

(b)

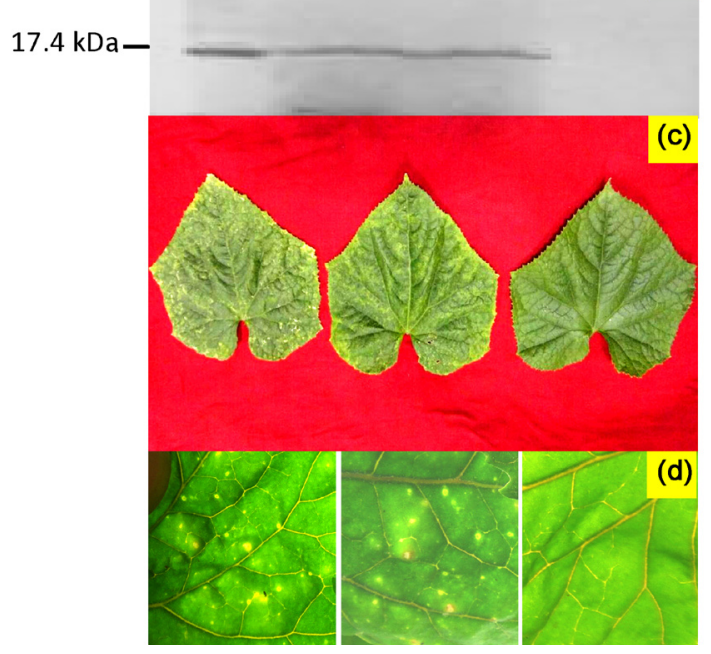

Fig. 4

The symptoms and detection of virus-specific gene or coat protein in plants inoculated with in vitro transcript RNAs from full-length cDNA clone (pT7CGBS) of chb isolate of cucumber green mottle mosaic virus (CGMMV-chb)

RT-PCR analysis for inoculated plant tissues with CGMMV (a); Western blot analysis of CGMMV coat protein hybridized with CGMMV antibody (b). Total nucleic acids or total protein samples were prepared from cucumber cotyledons or upper leaves. Wild CGMMV-chb total RNAs-inoculated upper leaf of cucumber (positive control, A1 and B1), transcripts-inoculated cotyledon of cucumber (A2 and B2), transcripts-inoculated upper leaf of cucumber (A3 and B3), phosphate buffer inoculated upper leaf of cucumber (negative control, A4 and B4). The symptoms of the upper leaf of cucumber and treated leaf of Ch. amaranticolor inoculated by wild CGMMV-chb total RNAs as positive control (C left and D left), upper leaf of cucumber and treated leaf of Ch. amaranticolor inoculated by transcripts (C middle and D middle), upper leaf of cucumber and treated leaf of Ch. amaranticolor inoculated by phosphate buffer as negative control ( $c$ right and $\mathrm{d}$ right). 
is a new emerging Tobamovirus on Cucurbitaceous plants and represents a serious threat to the production for the country (Ainsworth, 1935). CGMMV-chb was originally isolated from naturally grown watermelon plants in Hebei province of China which exhibited green mottle and mosaic symptoms on leaves and severe distortion symptoms (our unpublished results). At present, only three whole genome sequences of CGMMV isolates were reported in China. The lack of sequence data hinders the classification and evolution studies of the virus. The complete genome sequence of CGMMV-chb obtained in this study will be utilized to reveal the CGMMV classification status and virus evolutionary patterns.

The similarity and phylogenetic relationships of CGMMVchb with the other isolates had been analyzed. It showed that CGMMV-chb shared the highest identity with CGMMV$\mathrm{KW}$, which was found in Korea, not only for the complete genome sequence but also for each ORF. The two isolates also belong to the same sub-cluster in the phylogenetic tree, indicating that the two isolates may be evolutionarily closer than other isolates. The Cucurbitaceous plants import and export seed trade between Korea and China might be the reason for the introduction of the virus. The consequence is in accordance with Liu et al. (2009) and Tian et al. (2009). As the seed-borne virus, immediate attention should be paid to the use of certified seeds, investigation of effective seed treatment, and education of the farming community about the importance of phytosanitary measures in disease control. In addition, the four encoded proteins of the CGMMV-chb showed higher identities with the other CGMMV isolates in the nucleotide and amino acid levels. In particular, the amino acid sequence is very conservative. This probably indicates that some factors such as negative selection and bottleneck episodes can result in low genetic diversity and the small changes may play an important role for its evolution and prevalence (Kim et al., 2010). The four CGMMV isolates from China were clustered to one sub-group. It showed that the variation of the virus may be correlated with geographical origin and the climate factors. The result was in accordance with Li's finding (2010). Focusing on such genetic variability of CGMMV, this study could be a helpful baseline for understanding genetic characterization of CGMMV isolates and developing control strategies for the breeding of virus resistant cultivars and plant quarantine (Kim et al., 2010).

Using of infectious clones has become the most important tool to study the biology, pathogenesis, and virulence determinants of both positive and negative stranded RNA viruses (Bing et al., 2014). They also provided further insight on functions of different viral proteins or the mechanisms of interaction between viruses and their host plant or vector (Klein et al., 2014). The full-length clone of CGMMV was constructed for the first time by Ooi et al. (2006), for use as the vector for expression system for hepatitis B surface antigen. The infectivity of the full-length clone of CGMMV was not shown in detail. In our study, the full-length cDNA clone of CGMMV-chb was produced and evaluated for infectivity after T7 transcription in vitro (pT7CGBS). The symptoms were indistinguishable from those generated by inoculation of CGMMV wild strain RNA. The method was simplified compared with Ooi et al. (2006). Similar results for in vitro transcription with T7 promoter was reported for KGMMV (Mizumoto et al., 2010), ZGMMV (Wu et al., 2009) and CFMMV (Rhee et al., 2014). Production of the infectious cDNA clone of CGMMV-chb will facilitate the evaluation of mutants to investigate CGMMV-chb gene function and interactions with host plants (Yoon et al., 2001; Wu et al., 2009; Mizumoto et al., 2010).

Acknowledgements. We thank T. Zhou for providing local lesion host Chenopodium amaranticolor and Z. Li for providing pUC19 plasmid. This work was supported by National Nature Science Foundation (31201487), Hebei Nature Science Foundation (C2013204058) and Hebei Natural Science Foundation of Higher Education Institutions for Youth (YQ2014023).

\section{References}

Aguilar I, Sánchez F, Martín AM, Martinez-Herrera D, Ponz F (1996): Nucleotide sequence of Chinese rape mosaic virus (oilseed rape mosaic virus), a crucifer tobamovirus infectious on Arabidopsis thaliana. Plant. Mol. Biol. 30, 191-197. http://dx.doi.org/10.1007/BF00017814

Ainsworth GC (1935): Mosaic disease of cucumber. Ann. Appl. Biol. 22, 55-67. http://dx.doi.org/10.1111/j.1744-7348.1935. tb07708.x

Ali A, Natsuaki T, Okuda S (2004): Identification and molecular characterization of viruses infecting cucurbits in Pakistan. J. Phytopathol. 152, 677-682. http://dx.doi.org/10.1111/ j.1439-0434.2004.00915.x

Antignus Y, Pearlsman M, Ben-Yoseph R, Cohen S (1990): Occurrence of a variant of cucumber green mottle mosaic virus in Israel. Phytoparasitica 18, 50-56. http://dx.doi. org/10.1007/BF02980826

Bing T, Yu H, Li Y, Sun L, Tan J, Geng YQ, Qiao WT (2014) : Characterization of a full-length infectious clone of bovine foamy virus 3026. Virologica Sinica 29, 94-102. http:// dx.doi.org/10.1007/s12250-014-3382-5

Celix A, Luis-Arteaga M, Rodriguez-Cerezo E (1996): First report of cucumber green mottle mosaic tobamovirus infecting greenhouse-grown cucumber in Spain. Plant Dis. 80, 1303. http://dx.doi.org/10.1094/PD-80-1303C

Chen HY, Zhao WJ, Cheng Y, Li MF, Zhu YF (2006): Molecular identification of the virus causing watermelon mosaic disease in middle of Liaoning. Acta Phytopathol. Sin. 36, 198-200.

Chen J, Li MF (2007): An alien invasive pest-cucumber green mottle mosaic virus. Plant Quarantine 2, 94-96. 
Francki RIB, Hu J, Palukaitis P (1986): Taxonomy of cucurbit infecting tobamovirus as determined by serological and molecular hybridization analyses. Intervirology 26 , 156-163. http://dx.doi.org/10.1159/000149695

Ichiki TU, Nagaoka EN, Hagiwara K, Sasaya T, Omura T (2009): A single residue in the $126-\mathrm{kDa}$ protein of pepper mild mottle virus controls the severity of symptoms on infected green bell pepper plants. Arch.Virol. 154, 489-93. http:// dx.doi.org/10.1007/s00705-009-0312-1

Junqueira BRT, Nicolini C, Lucinda N, Orílio AF, Nagata T (2014): A simplified approach to construct infectious cDNA clones of a tobamovirus in a binary vector. J. Virol. Methods 198, 32-36. http://dx.doi.org/10.1016/j.jviromet.2013.12.024

Kim DH, Lee JM (2000): Seed treatment for Cucumber green mottle mosaic virus (CGMMV) in gourd (Lagenaria siceraria) seeds and its detection. J. Kor. Soc. Hort. Sci. 41, 1-6.

Kim OK, Mizutani TK, Natsuaki KT, Lee KW, Soe K (2010): First report and the genetic variability of cucumber green mottle mosaic virus occurring on bottle gourd in Myanmar. J. Phytopathol. 158, 572-575. http://dx.doi. org/10.1111/j.1439-0434.2009.01655.x

Kim SM, Lee JM, Yim KO, Oh MH, Park JW, Kim KH (2003): Nucleotide sequences of two Korean isolates of cucumber green mottle mosaic virus. Mol. Cells 16, 407-412.

Klein E, Brault V, Klein D, Weyens G, Lefèbvre M, Ziegler-Graff V, Gilmer D (2014): Divergence of host range and biological properties between natural isolate and full-length infectious cDNA clone of the Beet mild yellowing virus 2ITB. Mol. Plant Pathol. 15, 22-30. http://dx.doi.org/10.1111/ mpp.12061

Komuro Y, Tochihara H, Fukatsu R, Nagai Y, Yoneyama S (1968): Cucumber green mottle mosaic virus on watermelon in Chiba and Ibaraki Prefectures. Ann. Phytopathol. Soc. Jpn. 34, 377.

Lee KY (1996): Current occurrence and control of CGMMV Konjak disease. Plant Dis. Agric. 2, 38-39.

Lee KY, Lee BC, Park HC (1990): Occurrence of cucumber green mottle mosaic virus disease of watermelon in Korea. Korean J. Plant Pathol. 6, 250-255.

Li XY, Jiang BB, Wang X, Jing MF, Gong JF, Zhu XP (2010): Sequence analysis of $\mathrm{CP}$ gene of cucumber green mottle mosaic virus isolate infecting pumpkin from Shandong province. Shandong Agricultural Sciences 7, 1-4.

Liu Y, Wang Y, Wang X, Zhou G (2009): Molecular characterization and distribution of cucumber green mottle mosaic virus in China. J. Phytopathol. 157, 393-399. http://dx.doi. org/10.1111/j.1439-0434.2008.01509.x

Meshi T, Ishikawa M, Motoyoshi F, Semba K, Okada Y (1986): In vitro transcription of infectious RNAs from full-length cDNAs of tobacco mosaic virus. Proc. Natl. Acad. Sci.USA 83, 5043-5047. http://dx.doi.org/10.1073/ pnas.83.14.5043

Mizumoto H, Kimura K, Kiba A, Hikichi Y (2010): The 126and/or $183-\mathrm{kDa}$ replicases or their coding regions are responsible both for inefficient local and for systemic movements of Paprika mild mottle virus Japanese strain in tomato plants. Virus Res. 153, 205-211. http://dx.doi. org/10.1016/j.virusres.2010.08.002
Ooi AS, Tan SH, Mohamed R, Rahman NA, Othman RY (2006): The full-length clone of cucumber green mottle mosaic virus and its application as an expression system for Hepatitis B surface antigen. J. Biotechnol. 121, 471-481. http://dx.doi. org/10.1016/j.jbiotec.2005.08.032

Rhee SJ, Hong JS, Lee GP (2014): Infectivity and complete nucleotide sequence of cucumber fruit mottle mosaic virus isolate Cm cDNA. Arch. Virol. 159, 1807-1811. http:// dx.doi.org/10.1007/s00705-014-1990-x

Ryu SY, Hong JS, Rhee SJ, Lee G.P (2012): Brief report: genome sequence and construction of an infectious cDNA clone of Ribgrass mosaic virus from Chinese cabbage in Korea. Virus Genes 44, 345-348. http://dx.doi.org/10.1007/ s11262-011-0694-5

Song YS, Min BE, Hong JS, Rhie MJ, Kim MJ, Ryu KH (2006): Molecular evidence supporting the confirmation of Maracuja mosaic virus as a species of the genus Tobamovirus and production of an infectious cDNA transcript. Arch. Virol. 151, 2337-2348. http://dx.doi.org/10.1007/ s00705-006-0823-y

Tan SH, Nishiguchi M, Murata M, Motoyoshi F (2000): The genome structure of kyuri green mottle mosaic tobamovirus and its comparison with that of cucumber green mottle mosaic tobamovirus. Arch. Virol. 145, 1067-1079. http://dx.doi. org/10.1007/s007050070110

Tian YL, Liu DM, Zhang YJ, Li MF, Ma ZH (2009): Bioassay and genomic studies on the two isolates of Cucumber green mottle mosaic virus from Beijing and Shandong. Plant Quarantine 6, 1-6.

Ugaki M, Tomiyama M, Kakutani T, Hidaka S, Kiguchi T, Nagata R, Sato T, Motoyoshi F, Nishiguchi M (1991): The complete nucleotide sequence of cucumber green mottle mosaic virus (SH strain) genomic RNA. J. Gen. Virol. 72, 14871495. http://dx.doi.org/10.1099/0022-1317-72-7-1487

Vani S, Varma A (1993): Properties of cucumber green mottle mosaic virus isolated from water of river Jamuna. Indian. Phytopathol. 46, 118-122.

Weber H, Haeckel P, Pfitzner AJP (1992): A cDNA clone of tomato mosaic virus is infectious in plants. J. Virol. 66, 3909-3912.

Wu HW, Lin SS, Chen KC, Yeh SD, Chua NH (2009): Discriminating mutations of HC-Pro of zucchini yellow mosaic virus with differential effects on small RNA pathways involved in viral pathogenicity and symptom development. Mol. Plant. Microbe. In. 23, 17-28. http://dx.doi.org/10.1094/ MPMI-23-1-0017

Yoon JY, Min BE, Choi JK, Ryu KH (2002): Genome structure and production of biologically active in vitro transcripts of cucurbit-infecting Zucchini green mottle mosaic virus. Phytopathology92, 156-163. http://dx.doi.org/10.1094/ PHYTO.2002.92.2.156

Yoon JY, Min BE, Choi SH, Ryu KH (2001): Completion of nucleotide sequence and generation of highly infectious transcripts to cucurbits from full-length cDNA clone of Kyuri green mottle mosaic virus. Arch. Virol 146, 2085-2096. http://dx.doi.org/10.1007/s007050170022

Yu HH, Wong SM (1998): A DNA clone encoding the full-length infectious genome of odontoglossum ringspot tobamovirus 
and mutagenesis of its coat protein gene. Arch. Virol. 143, 163-171. http://dx.doi.org/10.1007/s007050050276

Zhang Y, Lartey RT, Hartson SD, Voss TC, Melcher U (1999): Limitations to tobacco mosaic virus infection of turnip.
Arch. Virol. 144, 957-971. http://dx.doi.org/10.1007/ $\underline{\mathrm{s} 007050050558}$ 